\title{
In silico Study of Centella asiatica Active Compound as BACE1 Inhibitor in Alzheimer's Disease
}

\author{
Nala Mawaddani ${ }^{1 *}$, Natalia RK Wibowo ${ }^{1}$, Qumaira HH Nadhira $^{1}$, Ratih Ayu Pramifta ${ }^{1}$ \\ ${ }^{1}$ Biology Department, Faculty Mathematics and Natural Sciences, Brawijaya University \\ Jl Veteran, No 1, Malang, 65145, Indonesia
}

Submission: April 2020; Revised: May 2020; Accepted: May 2020

* Corresponding author: Nala Mawaddani; e-mail: nalamawaddani@ gmail.com; tel.: 082232626640

\begin{abstract}
Alzheimer $(A D)$ is a chronical neurodegenerative disease which is the $6^{\text {th }}$ leading cause of death worldwide. About 36 million cases in the world and may increase to 115 million in 2050. The pathological cause of AD is the presence of residual $A \beta$ peptides. $A \beta$ peptides is produced in the cleavage process of the amyloid precursor protein (APP) sequentially by Beta amyloid precursor protein cleavage enzyme 1 (BACE1) and $\gamma$-secretase. Flavonol, germacrene B, and sitosterol are compounds found in Centella asiatica which is has potential as BACE1 inhibitor. The aim of this study was to analyze the interaction between BACE1 with flavonol, germacrene B and sitosterol by molecular docking to predict the BACE1 inhibitor potent of those compound. We obtained BACE1 from RSCB database, flavonol, germacrene $B$ and sitosterol from PubChem database. Molecular dockcing was done using Hex 8.0.0. The docking result were vizualized with Discovery Studio 3.5. Interaction of BACE1 resulted binding energy for sitosterol was $-239.7 \mathrm{kcal} / \mathrm{mol}$, flavonol was $-188.1 \mathrm{kcal} / \mathrm{mol}$, and germacrene B was $-185.6 \mathrm{kcal} / \mathrm{mol}$. Flavonol and sitosterol bound to the active site of BACE1 involving Thr232 and Ile110 on flavonol, while Tyr71 on sitosterol. All of the active compounds didn't have the interaction at SI' subsite, which is the center of BACE1 active site which has become the key of APP activation from BACE1. This study has shown that flavonol and sitosterol had potential to reduce BACE1 activity but not directly inhibit BACE1 activity.
\end{abstract}

Keywords: alzheimer's disease, BACE1, Centella asiatica, flavonol, germacrene B, sitosterol

\section{INTRODUCTION}

Alzheimer (AD) is a chronical neurodegenerative disease which ranked $6^{\text {th }}$ for the cause of death worldwide. There are about 36 million cases in the world and may increase to 115 million in 2050 [1]. The person who suffers from Alzheimer can experience the cognitive impairment and memory that can affect a person's quality of life. Neuropathological detection in AD can be done by reviewing the presence of $\beta$-amyloid $(A \beta)$ peptide biomarkers [2]. The accumulation of 40-42 amino acid residues of $A \beta$ peptides can be dangerous because it is one of factors that causes $\mathrm{AD}$ [3].

The formation of neurotoxic $A \beta$ is produced in the process of cleavage of the amyloid precursor protein (APP) sequentially by $\beta$-secretase or referred to as Beta amyloid precursor protein cleavage enzyme 1 (BACE1) and $\gamma$-secretase [3]. $A \beta$ can induce oxidative stress, activation of glial cells, apoptosis signal from neuron cells and accumulation of $A \beta$ indicating the death of neurons by limiting synaptic function [2]. The formation of A $\beta$ deposits can cause plaque in the brain parenchyma and cerebrovascular walls and the formation of neurofibril strands in the cortex and hippocampus followed by synaptic and neuron loss [4].

Researchers have taken several approaches through herbal therapy which is carried out as a treatment for $\mathrm{AD}$. One of them is using extract of Pegagan plant (Centella asiatica: Family Apiceae). Centella asicatica (CA) is one of the herbs that are spread in Southeast Asia, including Indonesia [5]. According to previous study, it shows that water extract of CA has biological effects of relevance to memory, learning, and aging, and potentially to disease progression in AD [6]. This plant contains several active compounds in the form of flavonoids, terpenoids, and polyphenols. Active compounds that exist in CA are thought to bind to BACE1 which BACE1 has been widely used as a target in the treatment of AD [3]. Inhibition of BACE1 will stop the formation of $A \beta$ at the beginning of cutting APP [5]. Inhibiting the formation of $A \beta$ in the initial phase is considered important and effective [3].

According to previous studies, the effectiveness of several CA active compound extracts in the treatment of AD through blocking BACE1 activity will be carried out using in silico virtual prediction 
to analyze the ability of these compounds in the process of suppressing $A \beta$ production so that it can be the basic for developing alternative drugs for $A D$ treatment. The purpose of this study is to analyses active compounds of CA that potentially inhibit the interaction of BACE1 and APP using molecular docking.

\section{METHODS}

\section{Proteins and Ligands Preparation}

The receptor used in this study is BACE1 was downloaded from https://www.rcsb.org with PDB ID: 1FKN. Protein were prepared with Discovery Studio 2016 client 3.5 [11] to remove water molecules and contaminant ligands. Ligands used are: flavonol (CID: 11349), germacrene B (CID: 5281519), sitosterol (CID: 222284), and lanabecestat (CID: 67979346) as control ligand. 3D Ligand structure obtained from PubChem. Ligands are prepared using PyRx [12] to minimize the binding energy and converted to PDB format.

\section{Ligand-Receptor Docking Analysis and Visualization}

The study was conducted with molecular docking by using HEX 8.0.0 [13] to predict interactions between active compounds in CA with BACE1 also to analyze the energy and types of bond between receptor-ligand complexes formed. The interactions reviewed in this study were: (1) BACE1-flavonol, (2) BACE1-germacrene B, (3) BACE1-sitosterol, and interactions with positive control were (4) BACE1-lanabecestat. Result of docking is visualized by Discovery Studio 2016 to see the result of the interaction and also the bonds that formed.

\section{RESULTS AND DISCUSSION}

The molecular docking between BACE1 with flavonol, germacrene $\mathrm{B}$, and sitosterol has been studied for investigation BACE1 inhibitor in $\mathrm{AD}$ pathway. Ligands are chosen for investigation because they fulfilled the molecular character that can across blood-brain barrier (BBB) which shown on Table 1. It is revealed that all compounds used in this study are eligible in terms of oral bioavailability. BBB is semi-permeable physiological barrier in the human central nervous systems (CNS) composed of complex multicellular systems of endothelial cells, astrocytes, pericytes, microglia, vascular smooth muscle cell, and neurons. This barrier located between the brain parenchyma and vascular system with various function as regulator of molecular transport to and from the brain, mediators of communication also separator between peripheral tissues and CNS, protecting the brain from systemic toxins as well as maintaining nutrient and ion levels suitable for neuronal function (homeostasis) [7]. Factors affecting penetration of compounds through BBB including: (1) molecular weight (MW) $<500 \mathrm{Da}$, (2) lipophilicity $(\log \mathrm{P}),(3)$ distribution coefficient (LogD), (4) topological polar surface area (TPSA) $<90 \AA$, (5) hydrogen bond donor (HBD), molecules with $<5 \mathrm{H}$-bond donor and $<10 \mathrm{H}$-bond receptor are better in absorption and penetrate the BBB, and (6) ionization of compound (pK) [8]. Molecules with TPSA value greater than $140 \AA^{2}$ tend to be weak at penetrating neuronal cells and BBB. In general, small molecules that target on CNS required TPSA value less than $90 \AA^{2}$ so it can easily pass through BBB [9].

The ligand-protein interaction was presented by binding sites on amino acid residue and the types of interaction shown in Table 2. The binding energy of BACE1 and sitosterol is the lowest among other ligands. Flavonol binds with 2 amino acid residues of BACE1, Thr232 and Ile110 form hydrogen and hydrophobic bond with the binding energy -188.1 $\mathrm{kcal} / \mathrm{mol}$. Interaction of BACE1 with germacrene B formed hydrophobic bond with the binding energy of $-185.6 \mathrm{kcal} / \mathrm{mol}$. Germacrene B bind with one amino acid residue of BACE1, Val93. Sitosterol binds to BACE1 through a hydrogen bond and 4 hydrophobic bond with total binding energy -239.7 $\mathrm{kcal} / \mathrm{mol}$.

Interaction between BACE1 and sitosterol involved 3 amino acid residues Leu30, Lys107, and Tyr71 which all of these residues located in subunit B of BACE1 (Figure 1). The results show that flavonol and sitosterol binds at the active site of BACE1. Flavonol binds with Thr232 and Ile110 at the active site while the sitosterol binds with Tyr71 at the active site. All of the ligands did not have the interaction at S1' subsite, the center of BACE1 active site which has become the key of APP activation from BACE1. It is known that BACE1 active site is large consisting of subsites called pockets. There are S1 pocket which has close proximity with $\mathrm{S} 3$ are hydrophobic region composed of Leu30, Phe108, Ile110, Ile118, and Trp115 residues; the $\mathrm{S} 2$ and $\mathrm{S} 4$ are site exposed to hydrophilic residues such as Lys9, Ser10, Thr72, Gln73, Thr231, Thr232, Arg235, Arg307, and Lys321; the S3' and S4' composed of Pro70, Thr72, Glu125 Arg128, Arg195, and Trp197 residues; then next to S4' are S2' subsites which composed of hydrophobic and amphipathic residues such as Ser35, Val69, Tyr71, Ile126, and Tyr198; also the center of the active site, the S1' subsite, contains the catalytic dyad of Asp32/Asp238 and two hydrophobic residues of Ile226 and Val 332 [10]. 

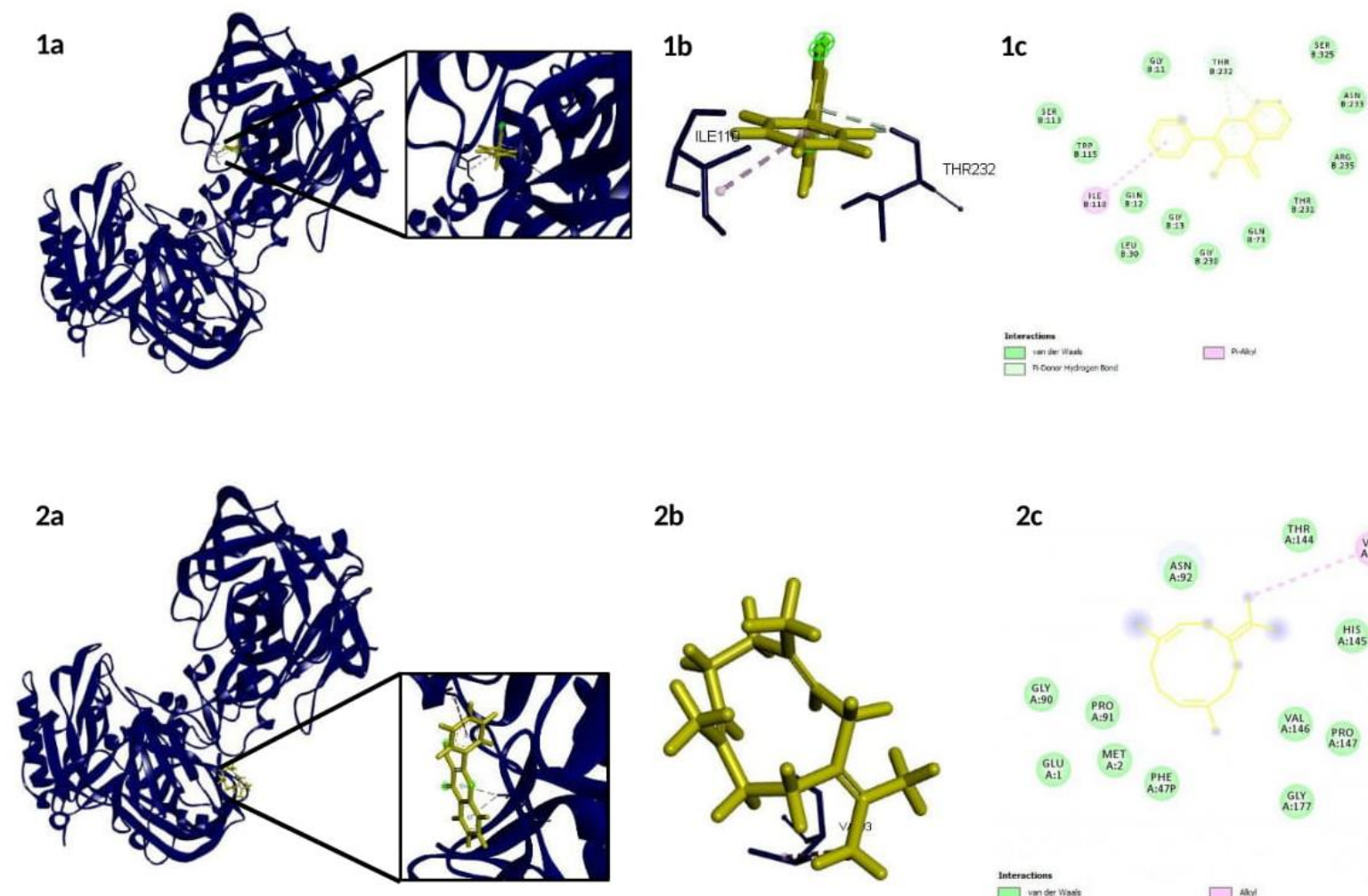

$2 b$
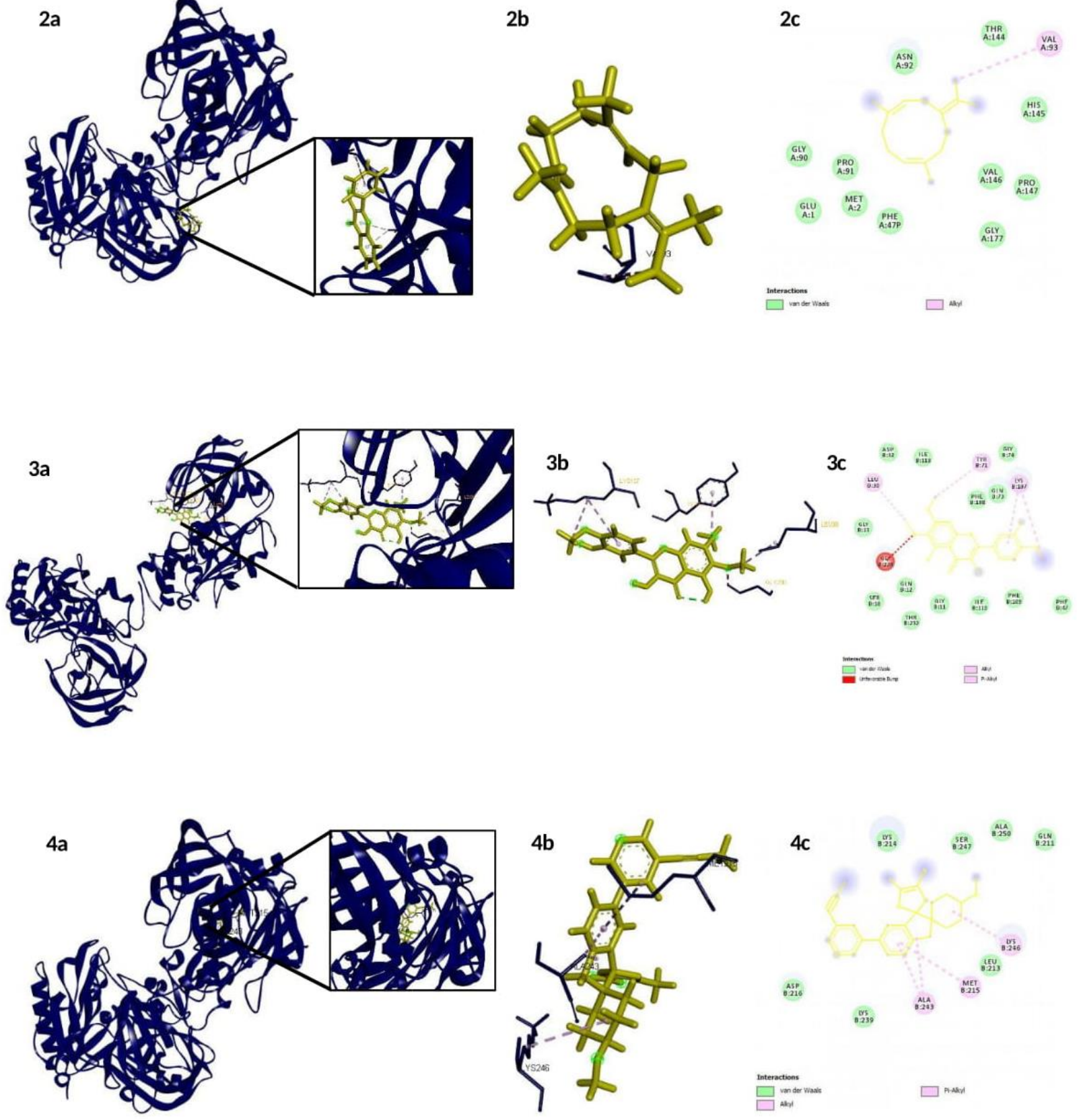

Figure 1. Molecular docking result of BACE1 with C. asiatica (1) flavonol, (2) germacrene B, (3) sitosterol, and (4) lanabecestat as control ligand. Letter ' $a$ ' shows an overview of flavonol/germacrene B/sitosterol/lanabecestatBACE1 complex; letter ' $b$ ' shows 3D structure of flavonol/germacrene B/sitosterol/lanabecestat-BACE1 complex; and letter 'c' shows 2D structure of flavonol/germacrene B/sitosterol/lanabecestat-BACE1 complex. 
Table 1. Size and TPSA value of compound used in this study.

\begin{tabular}{cccc}
\hline No & Compound & Size $(\mathbf{D a})$ & TPSA $(\AA)$ \\
\hline $\mathbf{1}$ & Lanabecestat & 412.5 & 72.9 \\
$\mathbf{2}$ & Flavonol & 238.24 & 46.5 \\
$\mathbf{3}$ & Germacrene B & 204.35 & 0 \\
$\mathbf{4}$ & Sitosterol & 414.7 & 20.2 \\
\hline
\end{tabular}

Table 2. Types of interaction between BACE1 with ligands.

\begin{tabular}{|c|c|c|c|c|c|c|c|}
\hline Interaction & $\begin{array}{l}\text { Interaction } \\
\text { Point }\end{array}$ & $\begin{array}{l}\text { Distance } \\
(\AA \mathbf{A})\end{array}$ & $\begin{array}{c}\text { From } \\
\text { Chemistry }\end{array}$ & $\begin{array}{c}\text { To } \\
\text { Chemistry }\end{array}$ & Type & $\begin{array}{l}\text { Chemistry } \\
\text { Bond }\end{array}$ & $\begin{array}{c}\text { Energy } \\
\text { Binding } \\
\text { (kcal/mol) }\end{array}$ \\
\hline \multirow{4}{*}{$\begin{array}{c}\text { BACE1 + } \\
\text { Lanabecestat }\end{array}$} & $\begin{array}{c}\text { B:ALA243 - } \\
\text { :LIG1 }\end{array}$ & 4.77 & Alkyl & Alkyl & Alkyl & $\begin{array}{l}\text { Hydrophobic } \\
\text { Bond }\end{array}$ & \multirow{4}{*}{-256.0} \\
\hline & $\begin{array}{l}\text { B:LYS246 - } \\
\quad \text { :LIG1 }\end{array}$ & 4.57 & Alkyl & Alkyl & Alkyl & $\begin{array}{l}\text { Hydrophobic } \\
\text { Bond }\end{array}$ & \\
\hline & $\begin{array}{c}\text { :LIG1 - } \\
\text { B:MET215 }\end{array}$ & 5.49 & Pi-Orbitals & Alkyl & Pi-Alkyl & $\begin{array}{l}\text { Hydrophobic } \\
\text { Bond }\end{array}$ & \\
\hline & $\begin{array}{c}\text { :LIG1 - } \\
\text { B:ALA243 }\end{array}$ & 5.03 & Pi-Orbitals & Alkyl & Pi-Alkyl & $\begin{array}{l}\text { Hydrophobic } \\
\text { Bond }\end{array}$ & \\
\hline \multirow{3}{*}{$\begin{array}{c}\text { BACE1 + } \\
\text { Flavonol }\end{array}$} & $\begin{array}{c}\text { B:THR232:HN } \\
- \text { :LIG1 }\end{array}$ & 3.18 & H-Donor & Pi-Orbitals & $\begin{array}{l}\text { Pi-Donor } \\
\text { Hydrogen } \\
\text { Bond }\end{array}$ & $\begin{array}{l}\text { Hydrogen } \\
\text { Bond }\end{array}$ & \multirow{3}{*}{-188.1} \\
\hline & $\begin{array}{c}\text { B:THR232:HN } \\
- \text { :LIG1 }\end{array}$ & 3.00 & H-Donor & Pi-Orbitals & $\begin{array}{l}\text { Pi-Donor } \\
\text { Hydrogen } \\
\text { Bond }\end{array}$ & $\begin{array}{l}\text { Hydrogen } \\
\text { Bond }\end{array}$ & \\
\hline & $\begin{array}{c}\text { :LIG1 - } \\
\text { B:ILE110 } \\
\end{array}$ & 4.69 & Pi-Orbitals & Alkyl & Pi-Alkyl & $\begin{array}{l}\text { Hydrophobic } \\
\text { Bond } \\
\end{array}$ & \\
\hline $\begin{array}{c}\text { BACE1 + } \\
\text { Germacrene B }\end{array}$ & $\begin{array}{l}\text { :LIG1:C- } \\
\text { A:VAL93 }\end{array}$ & 4.95 & Alkyl & Alkyl & Alkyl & $\begin{array}{l}\text { Hydrophobic } \\
\text { Bond }\end{array}$ & -185.6 \\
\hline \multirow{5}{*}{$\begin{array}{l}\text { BACE1 + } \\
\text { Sitosterol }\end{array}$} & $\begin{array}{l}\text { :LIG1:H - } \\
\text { :LIG1:O }\end{array}$ & 2.21 & H-Donor & H-Acceptor & $\begin{array}{l}\text { Conventional } \\
\text { Hydrogen } \\
\text { Bond }\end{array}$ & $\begin{array}{l}\text { Hydrogen } \\
\text { Bond }\end{array}$ & \multirow{5}{*}{-239.7} \\
\hline & $\begin{array}{l}\text { :LIG1:C - } \\
\text { B:LEU30 }\end{array}$ & 3.33 & Alkyl & H-Acceptor & Alkyl & $\begin{array}{l}\text { Hydrophobic } \\
\text { Bond }\end{array}$ & \\
\hline & $\begin{array}{l}\text { :LIG1:C - } \\
\text { B:LYS107 }\end{array}$ & 4.77 & Alkyl & Alkyl & Alkyl & $\begin{array}{l}\text { Hydrophobic } \\
\text { Bond }\end{array}$ & \\
\hline & $\begin{array}{l}\text { B:TYR71 - } \\
\text { :LIG1:C }\end{array}$ & 4.23 & Pi-Orbitals & Alkyl & Pi-Alkyl & $\begin{array}{l}\text { Hydrophobic } \\
\text { Bond }\end{array}$ & \\
\hline & $\begin{array}{c}: \text { LIG1 - } \\
\text { B:LYS107 }\end{array}$ & 4.75 & Pi-Orbitals & Alkyl & Pi-Alkyl & $\begin{array}{l}\text { Hydrophobic } \\
\text { Bond }\end{array}$ & \\
\hline
\end{tabular}

\section{CONCLUSION}

Flavonol and sitosterol bound to the active site of BACE1. Germacrene B bound to BACE1 but was not on its active site. All of the active compounds did not have the interaction at S1' subsite, which is the center of BACE1 active site which has become the key of APP activation from BACE1. Based on the effectiveness of binding energy form interaction BACE1 toward flavonol and sitosterol also their ability to bind on BACE1 active site, they said to be potential to reduce BACE1 activity but not directly inhibit BACE1 activity. This is because they did not bind on S1' subsite which is the center of BACE1 active as key of APP activation from BACE1.

\section{ACKNOWLEDGEMENTS}

We would like to acknowledge Brawijaya University that allows us to conduct this research. Also send our regards to Prof. Dra. Fatchiyah, M. Kes., Ph.D., Prof. Widodo, Ph.D.Med.Sc., Nia Kurniawan, S. Si, M.P., D.Sc., and Yoga Dwi Jatmiko, S.Si., M.App.Sc., Ph.D. and all laboratory assistants especially Feri Eko Hermanto for helping us to finish this research. 


\section{REFERENCES}

1. Li, Y., Sun, Z., Cao, Q., Chen, M., Luo, H., Lin, X., Xiao, F. 2017. Role of Amyloid $\beta$ Protein Receptors in Mediating Synaptic Plasticity. Biomed Rep. 6(4):379-386.

2. O'Brien, R. J., Wong, P. C. 2011. Amyloid Precursor Protein Processing and Azheimer's Disease. Annu Rev Neurosci. 34:185-204.

3. Kumalo, H. M., Soliman, M. E. 2016. A Comparative Molecular Dynamics Study on BACE1 and BACE2 Flexibility. Journal of Receptors and Signal Transduction. 36(5):505514.

4. Ahuja, M., Patel, M., Majrashi, M., Mulabagal, V., Dhanasekaran, M. 2017. Centella asiatica, an Ayurvedic Medicinal Plant, Prevents the Major Neurodegenerative and Neurotoxic Mechanisms Associated with Cognitive Impairment. Springer. New Delhi.

5. Gohil, K. J., Patel, J. A., A. Gajjar, K. 2010. Pharmacological Review on Centella asiatica: A Potential Herbal Cureall. Indian J Pharm Sci. 72(5):546-556.

6. Soumyanath, A., Zhong, Y., Henson, E. Wadsworth, T. Bishop, J., Gold, B., Quinn, J. 2012. Centella asiatica Extract Improves Behavioral Deficits in a Mouse Model of Alzheimer's Disease: Investigation of a Possible
Mechanism of Action. Int J Alzheimer. Dis: 381974. 1-9.

7. Malkiewicz, M. A., Szarmach, A., Sabisz, A., Cubala, Szurowska, W. J. E., Winklewski, P. J. 2019. Blood - Brain Barrier Permeabilit and Physical Exercise. J. Neuroinflammation. 16(15):1-16.

8. Geldenhuys, W. J., Mohammad, A. S., Adkins, C. E., P. Lockman, R. 2015. Molecular Determinants of Blood - Brain Barrier Permeation. Ther. Deliv. 6(7):961-971.

9. Srirangaramasamy, J., Sasikumar, A., Subamalani, S., Maheshraj, L. S., M. Balamurugan. 2019. Phytomolecules for Therapeutic Targets of Alzheimer's Disease Pathology - a Virtual Analysis. IJCMR. 6(6):12-14.

10. Mouchlis, V. D., Melagraki, G., Zacharia, L. C., Afantitis, A. 2020. Computer-Aided Drug Design of $\beta$-Secretase, $\gamma$-Secretase and Anti-Tau Inhibitors for The Discovery of Novel Alzheimer's Therapeutics. Int. J. Mol. Sci. 21(3):703.

11. Dassault Systèmes BIOVIA. 2017. Discovery Studio 2016 client 3.5 [Computer Software]. Retrieved from https://www.3dsbiovia.com.

12. Dallakian, Sarkis. 2009. PyRx [Computer Software]. Retrieved from https://sourceforge.net.

13. Ritchie, Dave. 2013. Hex 8.0.0 [Computer Software]. Retrieved from http://hex.loria.fr. 